\title{
Service Level Management of Information Technology and System in ITB STIKOM Bali
}

\author{
Nyoman Ayu Nila Dewi ${ }^{1 *}$ and A. A. Ngurah Bima Prasatria ${ }^{2}$ \\ ${ }^{1-2}$ Information System Department, Institut Teknologi dan Bisnis STIKOM Bali \\ Bali 80234, Indonesia \\ Email: ${ }^{1}$ nila@ stikom-bali.ac.id, ${ }^{2}$ bismaprasatria16@gmail.com
}

\begin{abstract}
ITB STIKOM Bali is a technology-based university so that all business processes, especially related to academics, student affairs, and finance, utilize information technology. Management of the information system and technology is carried out by the Computer and Network Center unit (Pusat Komputer dan Jaringan - PUSKOMJAR). In the management of Information Technology (IT) services, an agreement is needed in the form of Service Level Management (SLM) which contains the level of service, quality of service, and complaints handling, so users' needs are aligned with the system developer. Meanwhile, in managing the internal system of ITB STIKOM Bali, the agreement between PUSKOMJAR and related units is only in the form of submitting a form for making or changing the system. Therefore, it raises a problem if there is a mismatch in the manufacture or development of the system because there is no contract document that regulates in detail about the system. Hence, designing an SLM of IT and system services at ITB STIKOM Bali to overcome these problems is necessary. The research presents a case study by analyzing and designing the SLM of service system and IT in ITB STIKOM Bali. The applied research method is literature study and observation, analysis of existing SLM, designing new SLM, and conclusions. The result of the research is a document of SLM for internal IT and system services at ITB STIKOM Bali. Based on the analysis and design of SLM, the SLM document can help the PUSKOMJAR in documenting IT service information and making it easier for users to get information related to the provided IT services.
\end{abstract}

Index Terms-Service Level Management, Information Technology, Information System

\section{INTRODUCTION}

$\mathbf{N}$ OWADAYS, Information Technology (IT) is a fundamental requirement in organizations, companies, government agencies, and educational institutions $[1,2]$. The development of IT in all aspects encourages universities to take strategic steps so that they can excel in all fields. The role of IT in education is as a storehouse of knowledge, learning

Received: Dec. 29, 2020; received in revised form: Feb. 06, 2021; accepted: Feb. 08, 2021; available online: Aug. 16, 2021. *Corresponding Author aids, competency standards, education administration support, and education management tools [3]. Moreover, the reliability of IT services in higher education will increase its competitive advantage and answer the business needs. Therefore, universities should always look for approaches to develop IT services to increase user satisfaction and reduce costs and time [4].

ITB STIKOM Bali is a technology-based university so that all business processes, especially related to academics, student affairs, and finance, utilize IT. Management of systems and information technology at ITB STIKOM Bali is carried out by the Computer and Network Center unit (PUSKOMJAR). PUSKOMJAR manages all existing internal systems in ITB STIKOM Bali and handles the system development according to universities' current needs, which are very dynamic. In the management of IT services, an agreement is needed in the form of Service Level Management (SLM), which contains the level of service, quality of service, complaints handling, and others so that there is the alignment of users' needs with system developers. Service quality is also the key because it shows the variance between customers' perceptions of the obtained service and their expectations on service performance before providing the service [5]. Moreover, in managing the internal system of ITB STIKOM Bali, the agreement between PUSKOMJAR and related units is only submitting a form for making or changing the system. This situation raises a problem if there is a mismatch in the manufacture or development of the system because there is no contract document that regulates in detail about the system.

To overcome these problems, SLM is required. It is a process that aims to align business with service quality and determine customers' needs and expectations in an agreement between service providers and service users. SLM has several outputs, including Service Level Requirement (SLR), Service Level Agreement (SLA), and Operational Level Agreement (OLA). It is part of service delivery, which is one of the Informa- 
Cite this article as: N. A. N. Dewi and A. A. N. B. Prasatria, "Service Level Management of Information Technology and System in ITB STIKOM Bali", CommIT (Communication \& Information Technology)

Journal 15(2), 57-64, 2021.

tion Technology Infrastructure Library (ITIL) domains. Therefore, ITIL has been widely used as a guideline for designing SLM. For example, previous research uses ITIL Version 3 to design PUSAIR SLM [6].

There are several previous researchers related to SLM, especially in education. First, the previous research designs the SLR, SLA, and OLA with ITIL V3 in Institut Teknologi Sepuluh November (ITS) email services. The results are in the form of SLR documents containing the results of the wishes of ITS lecturers and staff regarding the email services. Then, the SLA document contains the service provider's capability for ITS email services. Meanwhile, the OLA document contains the capability of the Lembaga Pengembangan Teknologi Sistem Informasi (LPTSI) for ITS email services. The key performance indicator for ITS email service is email service availability, which is $98 \%$ of the services in one year, and the number of downtime for email services is less than five times in one year. The results are obtained from the calculation of the availability of ITS LPTSI communication [7]. Second, the previous research conducts 2014, 2016, 2017, and 2018 SLA analysis in the IT Department of Maranatha Christian University. The research analyzes the main components of the SLA to see 2014, 2016, 2017, and 2018 versions of the SLA. So, the research results can be used to measure the performance of sustainable IT services. The results show that the SLA is carried out according to the target. However, every IT service activity must be fully supported by complete documentation so that the next performance measurement can show a more reliable measurement [8].

Based on the previous research, the research will analyze and design an SLM of service system and IT in ITB STIKOM Bali. The difference between the research and previous research is that this research analyzes and designs SLM for all services provided by the IT unit and does not focus on one of the software services. The results document SLM of internal IT and system services in ITB STIKOM Bali. Then, the results can also be used as a reference for PUSKOMJAR in handling agreements related to system services and IT provided to internal units in ITB STIKOM Bali.

\section{LITERATURE REVIEW}

\section{A. Related Research}

Several previous studies related to SLM and SLA are carried out in various fields. For example, previous research by [9] designs SLA for information technology or system services in Telkom Polytechnic using ITIL. The application of the ITIL framework to the SLA process is done in the planning, analysis, and design stages. Based on the results of good analysis through interviews, documents, and surveys regarding the information technology or system service management process in this company, the obtained value in the survey is 2.88. It indicates that information technology or system service management has not been properly carried out and documented in SLA. This result is an answer to overcome weaknesses in information technology or system service management in Telkom Polytechnic.

Other than education, the previous research analyzes SLA of information and communication technology in Portuguese hospitals. It examines five Portuguese hospitals regarding their performance contracts and maintenance services. The preliminary results of the analysis of 38 proposals from the two hospitals indicate the need for significant improvements in the detailed specification of these contracts [10].

Reference [11] makes SLM on SAP of help desk services based on ITIL 2011 for a new Indonesian fertilizer company. The results of the SLM document are SLR, SLA, and OLA. A SAP of help desk job identification is carried out to create SLR documents. The identification of service requirements includes a list of service and service categorization. In preparing the SLA document, it is necessary to identify a list of services from service users. Then, it is adjusted to the capabilities of the service provider. Next, the document structure is prepared based on reference standards and adjusted to service needs to form a document structure of SLA. There are general information, description of services, services offered, communication between users and service providers that explains service reporting, procedures for handling requests and complaints, escalation, and a help desk channel. Meanwhile, to prepare OLA documents, identification of changes from SLA documents to OLA is conducted. It has the same document structure between SLA and OLA. However, there are a list of OLA in the service groups and different service times because it has been adjusted to the availability of SAP in help desk technicians.

\section{B. Information Technology Infrastructure Library (ITIL)}

ITIL defines IT as the use of technology for storing, communicating, or processing information. This technology generally includes computers, telecommunications, applications, and software. Meanwhile, the information may include business data, voice, image, video, and so on. In addition, IT is often used to support business processes through IT services [12]. At this time, the ITIL framework has been developed to the third version. The ITIL framework describes the stages of IT service management as a service lifecycle. 
Cite this article as: N. A. N. Dewi and A. A. N. B. Prasatria, "Service Level Management of Information Technology and System in ITB STIKOM Bali”, CommIT (Communication \& Information Technology)

Journal 15(2), 57-64, 2021.

There are five processes of service lifecycle in ITIL [13]. First, in service strategy, a strategy is developed to transform IT service management into a strategic asset of the organization. Second, service design refers to the development of an IT service management guide. It is based on the previously developed strategy at the service strategy stage. In addition, the guidelines are built based on the policies in the organization and to meet customer satisfaction. Third, it is service transition. At this stage, a transition process is carried out from the old governance to the new governance that has been developed in the service design stage. Fourth, service operation contains the best practice steps for IT service management. Fifth, in continual service improvement, the management of input from customers is done and collaborated into the four stages above. It aims to increase the output of the service strategy, service design, service transition, and service operation activities.

\section{Service Level Management (SLM)}

SLM is a process that exists in every IT service provider organization. In this SLM process, the responsibility is to approve and document service target levels in SLA and SLR documents for each service and activity related to IT. SLM aims to ensure that all service operations and service performance are measured consistently across the IT supply organization, and the generated reports meet the needs of businesses and customers. The most important things provided in the SLM process are SLA, OLA, and other support agreements. In addition, the SLM process also plans service improvements and service quality plans [14].

\section{Service Level Requirement (SLR)}

SLR is a statement regarding the need for new IT services or IT services to be changed. SLR documents are created to provide an overview of new or changed IT service levels. It is needed as a basis for making future SLA. In addition, SLR defines IT service guarantees. For example, it sees how the level of service required by users is, how secure the users' data are, how fast it is in fixing IT service problems, and what the level of IT service availability is. In the SLM process, SLR documents are only created when there is a change in service or the creation of a new service [11].

\section{E. Service Level Agreement (SLA)}

SLA is a legal document between the service provider and the service consumer. It is used to ensure the service quality that the consumers need from the provider. It defines the functional and non-functional requirements, such as reliability, availability, successability, accessibility, and others [15]. It is a contract between two parts (the provider and the customer) when the customer requests and receives a service from a provider [16]. It is also a key component of the overall SLM strategy of an IT organization. It contains information about the service target level and the responsibilities of users and IT service providers. Hence, it needs to pay attention to SLR documents or other necessary information related to IT service level needs in making SLA. It is also used as an IT service target level to ensure that the provided IT services by IT service providers can meet service quality through the achievement of the IT service target level. The contents of the SLA are the name of the service, a brief description of the service, hours of service, availability of services, reliability, service performance, sustainability of service, user support, security, change management, contact points and escalation, and responsibility [17].

\section{F. Operation Level Agreement (OLA)}

OLA is a prerequisite to support the existence of an SLA. It defines the availability of existing supporting facilities to integrate with the services. Generally, it has the same content as SLA, but the information has a higher level than SLA. Therefore, it is necessary to support the achievement of SLA. OLA refers to the responsibility of service providers for IT services and the provided services to users. The contents of OLA are the name of service, description of service support, hours of service, service target, contact points and escalation, service desk and incident response times and responsibilities, problem response time and responsibility, change management, service asset and configuration management, information security management, availability management, it service sustainability management, and capacity management [11].

\section{RESEARCH METHOD}

There are four stages in the research. The first stage is literature review and observation. In this stage, an exploration of concepts related to ITIL, SLM, Service Level Requirement, SLA, and OLA is carried out. Meanwhile, the observations are made in the PUSKOMJAR regarding internal services provided to all units in ITB STIKOM Bali. The second stage is an analysis of the existing SLM. The SLM analysis is conducted in the form of service level requirement, SLA, and OLA. Then, the third stage is the design of a new SLM. The design of a new SLM document is based on the results of the analysis referring to 
Cite this article as: N. A. N. Dewi and A. A. N. B. Prasatria, "Service Level Management of Information Technology and System in ITB STIKOM Bali”, CommIT (Communication \& Information Technology) Journal 15(2), 57-64, 2021.

TABLE I

Details of Institution’s Web Domain Management.

\begin{tabular}{ll}
\hline Component & Description \\
\hline \multirow{2}{*}{ Description } & $\begin{array}{l}\text { The management of the institutional web domain in the ITB STIKOM Bali is intended to support the smooth } \\
\text { running of teaching and learning activities and operational activities. This management is broadly used to evaluate } \\
\text { the implementation of the ITB STIKOM Bali web domain maintenance. It receives and checks subdomain submissions } \\
\text { from institutions and Student Activity Unit (Unit Kegiatan Mahasiswa - UKM). It also receives requests for additions } \\
\text { or changes to the STIKOM Bali subdomain submitted by institutions and UKM. }\end{array}$ \\
Scope & $\begin{array}{l}\text { This wireless network management service covers all institutions in ITB STIKOM Bali as well as UKM. } \\
\text { Clients }\end{array}$ \\
\hline
\end{tabular}

TABLE II

GAP ANALYSIS

\begin{tabular}{llll}
\hline Reviewed Aspects & Ideal State & Current State & Gap \\
\hline $\begin{array}{l}\text { Alignment between services } \\
\text { and system requirements. }\end{array}$ & $\begin{array}{l}\text { The management of system } \\
\text { and network services has an } \\
\text { agreement in the form of } \\
\text { SLM. }\end{array}$ & $\begin{array}{l}\text { Agreement in the form of the } \\
\text { submission form or system } \\
\text { change. }\end{array}$ & $\begin{array}{l}\text { The discrepancy in system de- } \\
\text { velopment is due to the ab- } \\
\text { sence of contract documents } \\
\text { regulating the system in de- } \\
\text { tail. }\end{array}$ \\
\hline
\end{tabular}

ITIL. Last, the fourth stage is the conclusions based on the results of analysis and design. It provides recommendations about the use of SLM documents.

\section{RESULTS AND DISCUSSION}

\section{A. Analysis of PUSKOMJAR Services}

PUSKOMJAR is a unit at ITB STIKOM Bali that specifically serves the management of the internal systems and networks. Meanwhile, external system services are handled by other units. From the results of observations and interviews, system services and IT handled by PUSKOMJAR for internal purposes include network and server management, bandwidth management, email management, wireless network management, and institution's web domain management. The research samples one of the services from PUSKOMJAR, which is the institution's web management. A detailed explanation of the institution's web management can be seen in Table I.

Implementation of network and system services by PUSKOMJAR refers to the existing standard operating procedures. Related documents during the service process are the form for submitting or changing the system without having a contract that regulates the system in detail. Based on the results of observations made, the PUSKOMJAR unit does not have an SLM document in providing services. Therefore, based on the analysis results, it finds the service gap analysis of PUSKOMJAR, as shown in Table II.

\section{B. Service Level Requirement (SLR) Design}

In preparing the SLR document, identification of service lists and service handling times is also done. It is according to the aspects expected by service users.
The structure and content of SLR documents for the institution's web management can be seen in Table III.

Table III shows the SLR of the institution's web domain management. It contains general information about the involved parties, a description of the services, and the offered services. The parties in this institution's web domain service are institutions at ITB STIKOM Bali and Student Activity Unit (Unit Kegiatan Mahasiswa - UKM). The service focuses on submitting subdomains, submitting UKM subdomains, and adding subdomains within the ITB STIKOM Bali environment. The institution's web domain management service can be submitted at any time and will be carried out by the staff when the application has been approved by the head of PUSKOMJAR.

\section{Service Level Agreement (SLA) Design}

In the SLA document preparation process, the research identifies the list of services. It is based on the SLR document. The structure and content of SLR documents for the institution's web management can be seen in Table IV.

Table IV shows the SLA of the institution's web domain management. It has general information about the involved parties, service descriptions, offered services, communication between customers and service providers, and service time. The offered services are submission of STIKOM, UKM, and additional subdomains in a web domain management service for institutions in the ITB STIKOM Bali environment. The procedure for the institution's web domain management service outlines the entire process, starting with submitting a subdomain application from the institution and UKM. Then, the head of PUSKOMJAR will accept 
Cite this article as: N. A. N. Dewi and A. A. N. B. Prasatria, "Service Level Management of Information Technology and System in ITB STIKOM Bali”, CommIT (Communication \& Information Technology) Journal 15(2), 57-64, 2021.

TABLE III

Service Level Requirement of Institution's Web Domain Management.

\begin{tabular}{lll}
\hline Chapter & Sub-Chapter & Contents \\
\hline General Information & Related Parties & $\begin{array}{l}\text { The institution's web domain management service involves several parties. It } \\
\text { is intended for operational management and academic processes. The involved } \\
\text { parties in this institution's web domain service are institutions in ITB STIKOM } \\
\text { Bali and UKM. }\end{array}$ \\
& $\begin{array}{l}\text { The institution's web domain management service supports all teaching and } \\
\text { learning activities and operational activities. This service focuses on submitting } \\
\text { subdomains, submitting UKM subdomains, and adding subdomains in the ITB } \\
\text { Description, Indicators of } \\
\text { Success, Service Users, } \\
\text { Service Start Date, and } \\
\text { Service End Date }\end{array}$ & $\begin{array}{l}\text { STIKOM Bali environment. The indicator of success in this service is that the } \\
\text { entire process of managing the institution's web domain starts with submitting }\end{array}$ \\
& $\begin{array}{l}\text { a subdomain application from the institution and UKM. Then, the head of } \\
\text { PUSKOMJAR will accept the request. After the request has been accepted, the } \\
\text { staff will check the submitted subdomain address. If the subdomain already } \\
\text { exists, the staff will inform the requester via email. Meanwhile, if the subdomain } \\
\text { does not exist, the institution will be informed via email. Users of this service are }\end{array}$ \\
& $\begin{array}{l}\text { PUSKOMJAR, institutions, and UKM. The institution's web domain manage- } \\
\text { ment services can be submitted at any time and will be carried out by staff when } \\
\text { the application has been approved by the head of PUSKOMJAR. }\end{array}$ \\
& $\begin{array}{l}\text { Application for institution's web domain management. } \\
\text { Institution's subdomain management and UKM subdomain management. }\end{array}$ \\
\hline Services & $\begin{array}{l}\text { Request for Changing Email } \\
\text { Service Availability }\end{array}$ & \\
\hline
\end{tabular}

TABLE IV

Service LeVel Agreement of Institution's Web Domain Management.

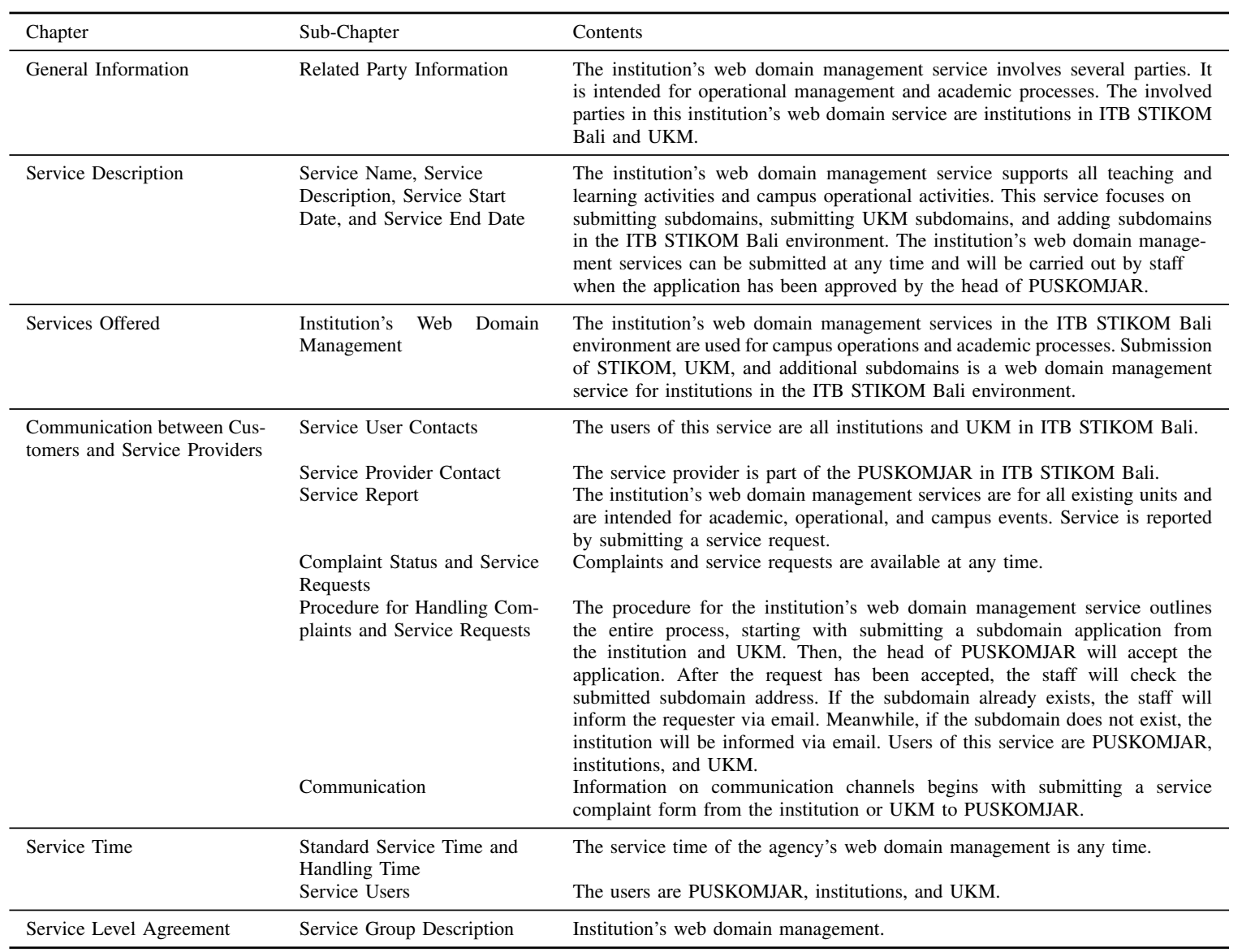

the application. After the request has been accepted, the staff will check the submitted subdomain address. If the subdomain already exists, the staff will inform the requester via email. Meanwhile, if the subdomain does not exist, the institution will be informed via email. Users of this service are PUSKOMJAR, institu- 
Cite this article as: N. A. N. Dewi and A. A. N. B. Prasatria, "Service Level Management of Information Technology and System in ITB STIKOM Bali”, CommIT (Communication \& Information Technology) Journal 15(2), 57-64, 2021.

TABLE V

Operation LEVEl REQUiREMENT OF Institution's Web Domain MANAGEMENT.

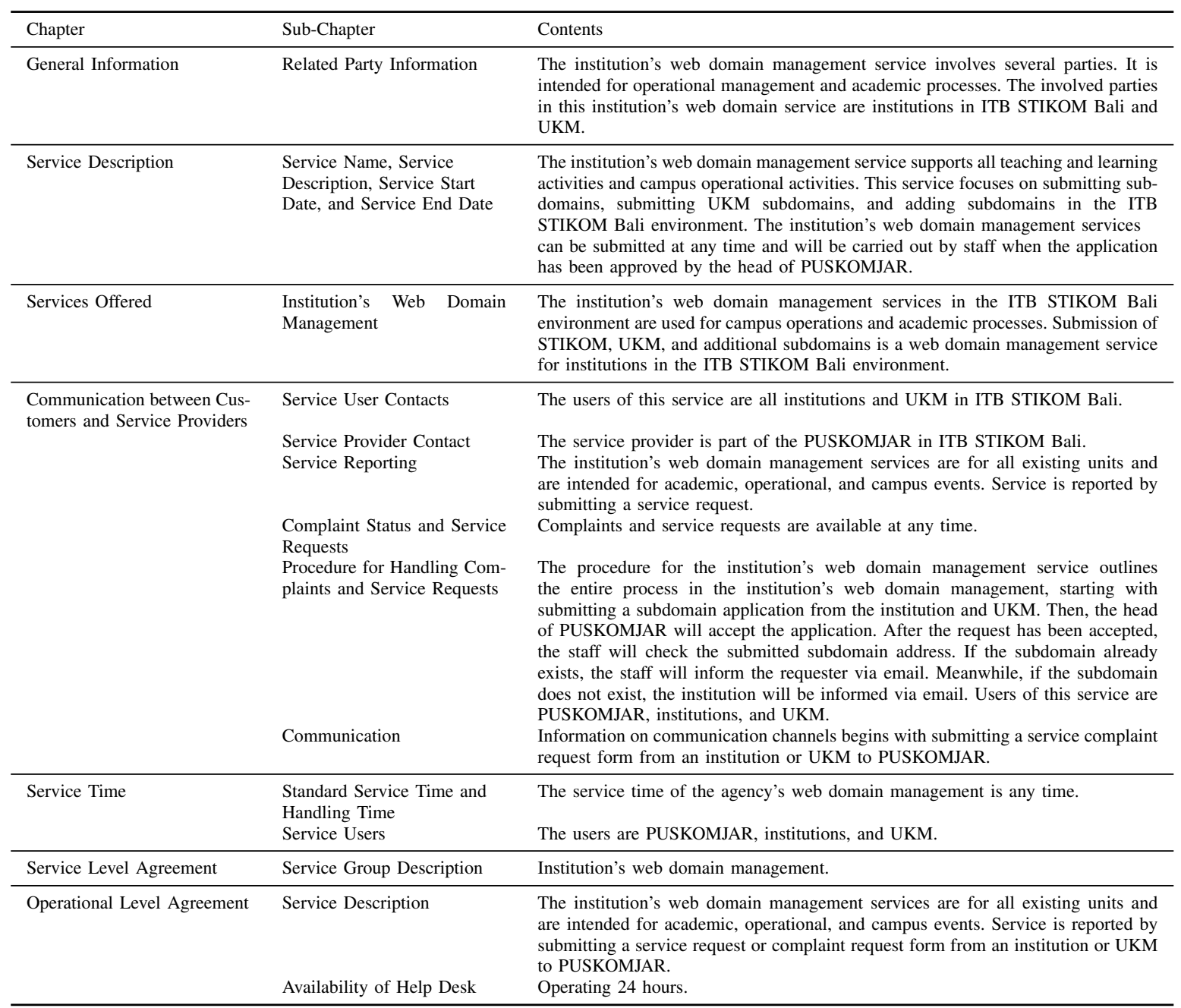

tions, and UKM.

\section{Operation Level Requirement (OLA) Design}

In preparing OLA documents, data and information are obtained from interviews with service providers. The structure and content of the OLA document are almost the same as the SLA document. However, there is an additional chapter, namely the operational level agents. The structure and content of OLA documents for the institution's web management can be seen in Table V.

Table V shows the OLA of the institution's web domain management. It includes general information about the involved parties, service descriptions, offered services, communication between customers and service providers, service time, SLA, and OLA. OLA explains how to submit requests and complaints. Then, the service and complaint are reported by submitting a service request or complaint request form from an institution or UKM to PUSKOMJAR. If there is a problem, the helpdesk is available and operates 24 hours.

\section{CONCLUSiON}

ITB STIKOM Bali is a technology-based university. All business processes, especially related to academics, student affairs, and finance, utilize information technology. Then, the management of the information system and technology is carried out by the PUSKOMJAR. In the management of IT services, an agreement is needed in the form of SLM, which contains the level of service, quality of service, and complaints handling. Meanwhile, in managing the internal system of ITB STIKOM Bali, the agreement between PUSKOMJAR and related units is only in the form of submitting a 
Cite this article as: N. A. N. Dewi and A. A. N. B. Prasatria, "Service Level Management of Information Technology and System in ITB STIKOM Bali”, CommIT (Communication \& Information Technology)

Journal 15(2), 57-64, 2021.

form for making or changing the system. Therefore, it raises a problem if there is a mismatch in system development because there is no contract document regulating the system in detail. It is necessary to design an SLM of IT and system services at ITB STIKOM Bali to overcome these problems. The research is only devoted to internal information technology and system services by PUSKOMJAR ITB STIKOM Bali.

The research result is a document of SLM for internal IT and system services in ITB STIKOM Bali. Two conclusions can be obtained based on the analysis and design of the SLM document. First, it can help the PUSKOMJAR document IT service information and make it easier for users to get information about the provided IT services. Second, it can also provide the same view between PUSKOMJAR and users regarding the agreed service level information. The suggestion for further research is to add a service maturity assessment of PUSKOMJAR to strengthen the SLM design.

\section{ACKNOWLEDGEMENT}

The research was supported by a grant from ITB STIKOM Bali in 2020. In addition, the authors are indebted to the ITB STIKOM Bali, which provided a grant to assist with the research.

\section{REFERENCES}

[1] I. G. A. K. Warmayana, "Pemanfaatan Teknologi Informasi dan Komunikasi (TIK) dalam meningkatan mutu Perguruan Tinggi Agama Hindu," Jurnal Penjaminan Mutu, vol. 4, no. 2, pp. 219-226, 2018.

[2] K. Aeni and R. Adzin, "ITSM strategy using CSI on ITIL V. 3 to improve IT services," INTENSIF: Jurnal Ilmiah Penelitian dan Penerapan Teknologi Sistem Informasi, vol. 4, no. 2, pp. 203214, 2020.

[3] S. Aswati, N. Mulyani, Y. Siagian, and A. Z. Syah, "Peranan sistem informasi dalam perguruan tinggi," Jurnal Teknologi dan Sistem Informasi, vol. 1, no. 2, pp. 79-86, 2015.

[4] A. Firmansyah, "Upaya peningkatan SLA pada IT service management di PT. Trikomsel Oke Tbk berdasarkan kerangka kerja ITIL V3,' Jurnal SIGMA, vol. 6, no. 2, pp. 105-111, 2017.

[5] W. J. A. Al-Nidawi, S. K. J. Al-Wassiti, M. A. Maan, and M. Othman, "A review in e-government service quality measurement," Indonesian Journal of Electrical Engineering and Computer Science, vol. 10, no. 3, pp. 1257-1265, 2018.

[6] D. M. Selvianti, Murahartawaty, and W. Herwindo, "Perancangan service catalogue management dan service level management pada layanan
IT PUSAIR dengan menggunakan framework ITIL versi 3," Jurnal Sistem Informasi, vol. 5, no. 4, pp. 436-445, 2015.

[7] T. D. Susanto, E. W. T. Darmaningrat, and A. F. Apriliana, "Pembuatan dokumen service level requirement, service level agreement dan operation level agreement pada layanan email ITS berbasis ITIL V3," in Seminar Nasional Sistem Informasi Indonesia (SESINDO), Surabaya, Jawa Timur, Nov. 1, 2016, pp. 149-154.

[8] T. Gantini, S. K. Yefta, B. W. Al Wafy, and L. B. Tantra, "Analisis SLA 2014, 2016, 2017 dan 2018 (Studi kasus di Departemen TI Universitas Kristen Maranatha)," Jurnal Teknik Informatika dan Sistem Informasi, vol. 5, no. 3, pp. 428-437, 2019.

[9] R. A. Putri and R. V. H. Ginardi, "Design the SLA of SIAKAD based on CMMI-SVC and ITILV3 framework," IPTEK Journal of Proceedings Series, no. 5, pp. 264-270, 2019.

[10] J. Lourenço, C. Santos-Pereira, R. Rijo, and R. Cruz-Correia, "Service level agreement of information and communication technologies in Portuguese hospitals," Procedia Technology, vol. 16, pp. 1397-1402, 2014.

[11] N. S. Prameswari, "Pembuatan service level requirement, service level agreement dan operational level agreement pada layanan help desk SAP berdasarkan kerangka kerja ITIL versi 2011 (Studi kasus: PT. Pupuk Indonesia Holding Company)," Bachelor's thesis, Jurusan Sistem Informasi, Institut Teknologi Sepuluh Nopember, 2016.

[12] A. P. Wijaya, P. Widiadnyana, and I. B. A. Swamardika, "Audit of information technology using ITIL V. 3 domain service operation on communications and information technology agency," International Journal of Engineering and Emerging Technology, vol. 1, no. 1, pp. 11-14, 2016.

[13] J. F. Andry and K. Christianto, "Evaluating maturity level using framework ITIL: A case study of Service Desk's," International Journal of Information Technology and Business, vol. 1, no. 1, pp. 16-23, 2018.

[14] M. Aziz, Murahartawaty, and E. K. Umar, "Perancangan service design pada layanan angkutan barang PT. Kereta Api Indonesia (persero) menggunakan framework ITIL versi 3," eProceedings of Engineering, vol. 2, no. 2, pp. 5351-5358, 2015.

[15] N. Sasikaladevi, "SLA based cloud service composition using genetic algorithm," International Journal of Advances in Intelligent Informatics, 
Cite this article as: N. A. N. Dewi and A. A. N. B. Prasatria, "Service Level Management of Information Technology and System in ITB STIKOM Bali”, CommIT (Communication \& Information Technology)

Journal 15(2), 57-64, 2021. vol. 2, no. 2, pp. 77-87, 2016.

[16] G. Iordache, A. Paschke, M. Mocanu, and C. Negru, "Service level agreement characteristics of monitoring wireless sensor networks for water resource management (SLAs4Water)," Studies in Informatics and Control, vol. 26, no. 4, pp. 379386, 2017.

[17] I. Maita and S. Akmal, "Analisis tata kelola teknologi informasi dengan best practice ITIL V3 service operation (Studi kasus: Pustaka dan Arsip Kampar)," Jurnal Ilmiah Rekayasa dan Manajemen Sistem Informasi, vol. 2, no. 1, pp. 60-65, 2016. 